\author{
MICHAŁ BERNACZYK \\ ORCID: 0000-0001-7683-8852 \\ Uniwersytet Wrocławski \\ Katedra Prawa Konstytucyjnego
}

\title{
DOSTĘP DO LIST POPARCIA KANDYDATÓW DO KRAJOWEJ RADY SĄDOWNICTWA JAKO PRZYKŁAD NEUTRALIZACJI AKSJOLOGICZNEJ KONSTYTUCJI RP
}

\begin{abstract}
Abstrakt: Artykuł omawia utrudnianie dostępu do informacji publicznej przez Kancelarię Sejmu (list poparcia kandydatów do Krajowej Rady Sądownictwa) mimo jej zasadniczego znaczenia dla oceny konstytucyjności Rady. Wątpliwości wyrażone przez TSUE w wyroku z dnia 19 listopada 2019 roku (w połączonych sprawach C-585/18, C-624/18 i C-625/18), podzielone przez Sąd Najwyższy w uchwale BSA I-4110-1/20 z 23 stycznia 2020 roku, można sprowadzić do wymogu weryfikacji całego procesu powoływania członków, ze szczególnym uwzględnieniem inspekcji papierowych dokumentów posiadanych przez Kancelarię Sejmu. Bezwnioskowe udostępnienie tych list nastąpiło w lutym 2020 roku, w sytuacji, w której status Rady został już rozstrzygnięty w uchwale Sądu Najwyższego. Pomimo solidnych podstaw konstytucyjnych dla dostępu do tego rodzaju informacji (art. 54, 61 Konstytucji RP) praktyczny problem z egzekwowaniem Konstytucji RP tkwi w mało skutecznej regulacji ustawowej, jak na ironię osłabionej przez władzę sądowniczą, pierwszą ofiarę kultury tajności, oraz dużą niechęć uczestników życia politycznego (w tym opozycji) do zwiększenia poziomu przejrzystości w parlamentarno-gabinetowym systemie rządów. Artykuł dowodzi, że kwestia zakresu i efektywności ustawowego reżimu dostępu do informacji nie może być zakładnikiem politycznego kompromisu, ilekroć informacja ma kluczowe znaczenie dla zachowania porządku konstytucyjnego.
\end{abstract}

Słowa kluczowe: Krajowa Rada Sądownictwa, prawo do informacji o działalności władzy publicznych, Konstytucja RP, podział władzy, niezależność sądownictwa, Sejm, jawność

\section{WPROWADZENIE. ZNACZENIE PRAWNE DOSTĘPU DO LIST POPARCIA KANDYDATÓW DO KRAJOWEJ RADY SĄDOWNICTWA}

Niniejszy tekst dotyczy najgorętszego problemu prawnego (a wręcz prawnomiędzynarodowego) ostatnich dwóch lat, jakim jest dostęp do tak zwanych list poparcia sędziów-kandydatów na członka Krajowej Rady Sądownictwa (dalej: KRS), nazwanych w ustawie z dnia 12 maja 2011 roku o Krajowej Radzie Sądownictwa ${ }^{1}$

${ }^{1}$ Tekst jedn. z dnia 5 grudnia 2018 roku (Dz.U. z 2019 r. poz. 84), dalej: u.KRS. 
„wykazem [obywateli bądź czynnych zawodowo sędziów - M.B.] popierających zgłoszenie kandydata na członka Rady" (zob. art. 11a ust. 2 pkt 1-2, art. 11b ust. 1, art. $11 \mathrm{~b}$ ust. 7 u.KRS). Problem jawności i prawidłowości sporządzenia tych wykazów ma i będzie mieć charakter węzłowy, gdyż od prawidłowości procedury wyboru członków KRS² (nie rozwodząc się w tym miejscu nad jej wątpliwą konstytucyjnością $\left.{ }^{3}\right)$ zależy prawidłowość czynności opiniodawczo-nominacyjnych dokonywanych przez KRS, a przede wszystkim wniosków o powołanie do pełnienia urzędu sędziego, adresowanych do Prezydenta RP (zob. art. 44a ustawy z dnia 12 maja 2011 roku o Krajowej Radzie Sądownictwa, dodany z dniem 17 stycznia 2018 roku). Kategorycznie podkreśla to uchwała składu połączonych Izb Sądu Najwyższego - Cywilnej, Karnej oraz Pracy i Ubezpieczeń Społecznych, zasada prawna z dnia 23 stycznia 2020 roku (BSA I-4110-1/20) ${ }^{4}$, a dokładnie pkt 36 uzasadnienia:

2 Zgodnie z art. 11a ust. 2 u.KRS „Podmiotami uprawnionymi do zgłoszenia kandydata na członka Rady jest grupa co najmniej: 1) dwóch tysięcy obywateli Rzeczypospolitej Polskiej, którzy ukończyli osiemnaście lat, mają pełną zdolność do czynności prawnych i korzystają z pełni praw publicznych; 2) dwudziestu pięciu sędziów, z wyłączeniem sędziów w stanie spoczynku".

${ }^{3}$ Zagadnienie wymagałoby przeprowadzenia w niniejszym tekście rozważań pokazujących metodykę wykładni przepisów art. 187 ust. 1 pkt 2 Konstytucji RP z uwzględnieniem dyrektyw wykładni sformułowanych przez Trybunał Konstytucyjny. Wymogi redakcyjne tomu na to jednak nie pozwalają, aczkolwiek rodzą się tutaj dwa zasadnicze pytania: czy ustrojodawca powiedział mniej, niż chciał powiedzieć (członkowie wybierani „,spośród”, ale „przez kogo/co”? Sędziów czy Sejm?) i co było granicą celu normy ustrojodawcy? Nie wchodząc w metodykę wykładni i przebieg wnioskowania, interpretator musi uwzględnić relację zachodzącą między zasadami przewodnimi ustroju (wstęp, rozdział I, zasady ogólne rozdziału II) a regułami (normami konstytucji w ścisłym tego słowa znaczeniu). Rozstrzyganie ewentualnych dylematów dotyczących znaczenia szczegółowego przepisu w rozdziale VIII musi zawsze łączyć się z pytaniem o to, który z możliwych wyników spełnia w najwyższym stopniu nakaz optymalizacyjny z art. 10 ust. 1 Konstytucji RP, to jest nakaz odseparowania władzy sądowniczej od pozamerytorycznego wpływu. Wariant interpretacyjny, w którym norma dozwala na przypisanie tej kompetencji Sejmowi pozostaje w silnej kontrze do zasad przewodnich ustroju. Oczywiście większość parlamentarna (wręcz ze swej istoty) przywołuje argument zakorzeniony w art. 4 Konstytucji RP, ale należy mieć śmiałość, aby taktownie wskazywać politykom dekontekstualizację pojęcia „naród” (art. 4 ust. 1) i przedstawicielskiego sprawowania władzy (art. 4 ust. 2) w sposób wypaczający pojęcie demokracji i państwa prawnego (szerzej i trafnie na temat znaczenia zasady suwerenności narodu zob. R. Piotrowski, Demokracja nieliberalna, czyli oksymoron konstytucyjny, [w:] Potentia non est nisi ad bonum. Księga Jubileuszowa dedykowana Profesorowi Zbigniewowi Witkowskiemu, red. M. Serowaniec, A. Bień-Kacała, A. Kustra-Rogatka, Toruń 2018, s. 610). Nie wolno też zignorować faktu, że o przepisach KRS wypowiedział się dwukrotnie Trybunał Konstytucyjny (w wyrokach z dnia 25 marca 2019 roku, sygn. K 12/18 i z dnia 20 czerwca 2017 roku, sygn. K 5/17), aczkolwiek w doktrynie pomija się tę okoliczność wymownym milczeniem (por. S. Patyra, Krajowa Rada Sadownictwa w Polsce, [w:] Rady sadownictwa w wybranych krajach europejskich, red. R. Balicki, S. Grabowska, M. Jabłoński, „Przegląd Prawa i Administracji” 119, Wrocław 2019, s. 125-134). Może to być zresztą bardzo racjonalne podejście z uwagi na delegitymizację tego organu wskutek naruszenia trybu wyboru sędziów (por. skład orzekający w sprawie K 12/18) bądź wystosowanie wniosku przez wadliwie ukonstytuowaną KRS (zob. wniosek w sprawie K 5/17).

${ }^{4}$ Opublikowana w bazie orzeczeń SN: www.sn.pl. 
Warunki minimalne wykonania omawianej prerogatywy przez Prezydenta RP [powołania sędziego - M.B.] wymagają więc, by inicjatorem jego działania był prawidłowo powołany i obsadzony organ mający status Krajowej Rady Sądownictwa. W okresie od wejścia w życie ustawy z dnia 8 grudnia 2017 r. o zmianie ustawy o Krajowej Radzie Sądownictwa oraz ustawy o SN z 2017 r. Krajowa Rada Sądownictwa nie była obsadzona w sposób wymagany przepisami Konstytucji RP, nie mogła zatem wykonywać przypisanych jej kompetencji, co Prezydent RP powinien był stwierdzić przed podjęciem decyzji o wykonaniu prerogatywy.

Uchwała Sądu Najwyższego jest oczywistą konsekwencją wcześniejszego (i bodaj najsłynniejszego w historii współczesnej Polski) wyroku Trybunału Sprawiedliwości Unii Europejskiej z dnia 19 listopada 2019 roku w sprawie A.K. $i$ in., C-585/18, C-624/18 i C-625/185. Bogactwo wątków i zarys metodyki badania przymiotu niezależnego i niezawisłego sądu w rozumieniu art. 47 Karty Praw Podstawowych oraz art. 6 EKPCz nie będą tu szczegółowo charakteryzowane $\mathrm{z}$ powodów czysto redakcyjnych ${ }^{6}$. Podkreślam jednak przełożenie postulowanej przejrzystości procedury dochodzenia do urzędu sędziego na dostęp do list poparcia kandydatów do KRS. Wynika on między innymi z punktów 139, 140, 141 oraz 171 wyżej wymienionego wyroku.

\section{GENEZA I KASKADOWOŚĆ PROBLEMÓW WYNIKAJĄCYCH Z NOWELIZACJI USTAWY O KRAJOWEJ RADZIE SĄDOWNICTWA W 2017 ROKU}

Sejm RP 8 grudnia 2017 roku uchwalił ustawę o zmianie ustawy o Krajowej Radzie Sądownictwa oraz niektórych innych ustaw ${ }^{7}$. Nowela weszła w życie 17 stycznia 2018 roku. Zasadniczym i najobszerniejszym jej elementem była zmiana trybu wyboru członków Krajowej Rady Sądownictwa. Trzon tej nowelizacji polegał na zmianie art. 9 u.KRS oraz dodaniu do niej art. 11a-11e, regulujących tryb wyboru grupy członków, o których mowa w art. 187 ust. 1 pkt 2 Konstytucji z dnia 2 kwietnia 1997 roku$^{8}$. Większość polityczna w Sejmie i Senacie zinterpretowała milczenie przepisu art. 187 ust. 1 pkt 2 Konstytucji RP w kwestii podmiotu uprawnionego do dokonania wyboru jako dozwolenie na przekazanie tej kompetencji

${ }^{5}$ ECLI:EU:C:2019:982.

${ }^{6}$ Ustawodawca zdecydował się odpowiedzieć na ten wyrok w sposób ewidentnie konfrontacyjny, wykluczając poszanowanie zasady efektywności prawa UE lub wręcz poddając zagadnienia interpretacyjne nakazane sędziom na mocy art. 9 i 91 ust. 2 i 3 Konstytucji RP sankcjom dyscyplinarnym; zob. ustawę z dnia 20 grudnia 2019 roku o zmianie ustawy - Prawo o ustroju sądów powszechnych, ustawy o Sądzie Najwyższym oraz niektórych innych ustaw (Dz.U. z 2020 r. poz. 190), zwaną pospolicie „ustawą kagańcową".

${ }^{7}$ Ustawa z dnia 8 grudnia 2017 roku o zmianie ustawy o Krajowej Radzie Sądownictwa oraz niektórych innych ustaw (Dz.U. z 2018 r. poz. 3).

${ }^{8}$ Dz.U. z 1997 r. Nr 78, poz. 483 ze zm., dalej: Konstytucja RP. 
Sejmowi ${ }^{9}$. Wybór grupy sędziów-członków KRS następuje więc nadal spośród sędziów, ale bez czynnego prawa głosu tych ostatnich. Jednocześnie art. 6 noweli wyeliminował ze składu KRS sędziów wybranych w sposób wolny od czynnika politycznego, skracając ich kadencję bez uzasadnionych konstytucyjnie przyczyn ${ }^{10}$.

W efekcie Sejm uzyskał możliwość przytłaczającego (pod względem ilościowym) wpływu na obsadę dwudziestopięcioosobowej KRS, wybierając spośród posłów czterech członków na okres czterech lat (art. 9 ust. 1 ustawy o KRS) oraz piętnastu członków na wspólną czteroletnią kadencję spośród sędziów Sądu Najwyższego, sądów powszechnych, administracyjnych i wojskowych. Pamiętając o dwóch członkach wybieranych przez Senat spośród senatorów (art. 9 ust. 2 ustawy o KRS), należy pamiętać, że mówimy o kompetencjach kreacyjnych w systemie parlamentarnym, w wypadku którego mechanizm inwestytury parlamentarnej (art. 154 Konstytucji RP) sprzyja politycznej symbiozie między sejmową większością polityczną a Radą Ministrów, zniechęcając do powściągania tej ostatniej (zob. art. 155 ust. 2 Konstytucji RP). Dopuszczalna unia personalna parlamentarzysty i ministra sprawiedliwości (przy czym ten ostatni ma wachlarz kompetencji w prawie o ustroju sądów powszechnych, a ponadto po raz kolejny został wzmocniony połączalnością urzędu prokuratora generalnego; zob. art. 103 ust. 1 zdanie drugie Konstytucji RP; art. $1 \S 2$ zdanie drugie ustawy z dnia 28 stycznia 2016 roku - Prawo o prokuraturze ${ }^{11}$ ) zwiększa siłę oddziaływania na organ, którego jedyną konstytucyjną funkcją jest „stanie na straży niezależności sądów i niezawisłości sędziów". Tych politycznych wpływów nie równoważy w żadnej mierze podstawowy sejmowy tryb wyboru członków KRS większością kwalifikowaną (trzech piątych głosów w obecności co najmniej połowy ustawowej liczby posłów; art. 11d ust. 5 u.KRS), który w wypadku fiaska jest łagodzony przez wymóg uzyskania bezwzględnej większości głosów w obecności co najmniej połowy ustawowej liczby posłów (art. 11d ust. 5 u.KRS).

Można dodać, że tak szerokich kompetencji kreacyjnych władza ustawodawcza w stosunku do KRS nie miała nawet w momencie jej utworzenia. Przypomnijmy, że miało to miejsce jedynie w schyłkowym okresie PRL-u ${ }^{12}$, kiedy ustrój

${ }^{9}$ Należy dodać, że przedłożenie było efektem prezydenckiego projektu ustawy z dnia 26 września 2017 roku (zob. druk nr 2002 Sejmu VIII kadencji). Próbę przebudowania systemu władzy sądowniczej, w tym KRS, podjęto już wcześniej, w projekcie ustawy z dnia 14 marca 2017 roku, wniesionym przez Radę Ministrów, który — mimo uchwalenia 12 lipca 2017 roku — zakończył się fiaskiem z powodu prezydenckiego weta zgłoszonego w cieniu masowych protestów społecznych. Dlatego z perspektywy tych wydarzeń można mówić o opóźnieniu reformy KRS, lecz nie o jakiejkolwiek korekcie zgodnej z Konstytucją RP; szerzej na temat postępowań ustawodawczych w 2017 roku zob. S. Patyra, op. cit., s. 130-131 i powołane tam stanowiska krytyczne.

${ }^{10}$ Zob. pkt III.6 uzasadnienia prawnego wyroku TK z dnia 18 lipca 2007 roku, sygn. K 25/07, opublikowanego w Internetowym Portalu Orzeczeń Trybunału Konstytucyjnego (dalej: IPOTK).

11 Tekst jedn. Dz.U. z 2019 r. poz. 740.

12 Por. art. 6 ustawy z dnia 20 grudnia 1989 roku o Krajowej Radzie Sądownictwa (Dz.U. z 1989 r. Nr 73, poz. 435). Krajowa Rada Konstytucyjna pojawiła się w Konstytucji PRL na mocy 
Polski był znacznie głębiej zanurzony w koncepcji jednolitości władzy państwowej ${ }^{13}$. Był to godny aprobaty czynnik stopniowo demokratyzujący Polskę i samoograniczający dominującą rolę Sejmu, z którą trudno było się rozstać. Kilkanaście lat później wciąż podkreślano związek funkcji kreacyjnych Sejmu i Senatu RP z koncepcją „kierownictwa państwowego" minionego ustroju ${ }^{14}$. Wyodrębnienie funkcji kreacyjnej parlamentu opisywano wręcz jako działanie szkodliwe dla podziału i równoważenia władz ${ }^{15}$. Na tym tle model KRS okazał się rozwiązaniem udanym, o niekwestionowanej niezależności, aby z nadejściem 2018 roku stać się

organem uwikłanym w polityczne i partyjne zależności, przez co niewiarygodnym dla środowiska sędziowskiego jako patron wartości wyrażonych w art. 186 ust. 1 Konstytucji. Utraciła też swój pierwotny charakter swoistego forum komunikacji władzy ustawodawczej, wykonawczej i sądowniczej. Tymczasem komunikacja jest wszak conditio sine qua non realizacji dyrektywy współdziałania władz, wyrażonej w preambule do Konstytucji ${ }^{16}$.

Po akcesji Polski do Unii Europejskiej w doktrynie wyrażano oczekiwanie, że pozycja konstytucyjna KRS ukształtowana w okresie transformacji wejdzie w nową fazę, orientując KRS na pogłębianie integracji polskiego sądownictwa i materialnych podstaw wymiaru sprawiedliwości z porządkiem prawnym Unii Europejskiej ${ }^{17}$. Nikt nie przypuszczał, że kilkanaście lat później ustrój KRS stanie się przyczynkiem do rozpatrywania tego organu w kategoriach czynników erozji tego porządku, a zwłaszcza osłabiania instytucjonalnych gwarancji prawa do sądu (art. 47 Karty Praw Podstawowych ${ }^{18}$ ). Punkt 50 wskazanej wcześniej uchwały SN z 20 stycznia 2020 roku stanowczo stwierdza, że pozycja KRS w systemie organów państwa cechuje się „strukturalnym uzależnieniem [...] od władzy politycznej”.

nowelizacji z dnia 7 kwietnia 1989 roku (ustawa o zmianie Konstytucji Polskiej Rzeczypospolitej Ludowej, Dz.U. z 1989 r. Nr 19, poz. 101).

${ }^{13}$ S. Patyra ocenia, że ostateczne odejście od zasady jednolitości państwowej nastąpiło z chwilą wejścia w życie małej konstytucji w 1992 roku; zob. idem, op. cit., s. 123.

${ }^{14}$ Por. na ten temat rozważania W. Sokolewicz, Funkcja kreacyjna Sejmu i Senatu, [w:] Parlament. Model konstytucyjny a praktyka ustrojowa, red. Z. Jarosz, Warszawa 2006, s. 148. Na marginesie warto dodać, że badacz ten nie zaliczał art. 187 ust. 1 pkt 2 Konstytucji RP do kategorii funkcji kreacyjnej odniesionej do organów władzy sądowniczej — ibidem, s. 150.

15 ,[W]yodrębnienie funkcji kreacyjnej hamuje, moim zdaniem, i tak niełatwy proces przezwyciężania przez parlament nawyków ukształtowanych wówczas, gdy wyraźnie dominował on w systemie władzy państwowej, a więc zajmował on pozycję zwierzchnią wobec innych organów mimo istnienia trójpodziału władzy" — ibidem, s. 148, z powołaniem na H. Suchocka, Zasada podziału i zrównoważenia władz, [w:] Zasady podstawowe polskiej konstytucji, red. W. Sokolewicz, Warszawa 1998, s. $157 \mathrm{n}$.

16 S. Patyra, op. cit., s. 133-134.

${ }^{17}$ Por. konkluzje A. Bałabana dotyczące dostosowywania władzy sądowniczej do „wyzwań naszych czasów"; zob. idem, Krajowa Rada Sadownictwa - regulacja konstytucyjna i rola w systemie władzy sądowniczej, [w:] Sąy i trybunały w Konstytucji i praktyce, red. W. Skrzydło, Warszawa 2005, s. 88.

18 Dz.Urz. UE 2016 C 202, s. 1. 
Ograniczenia redakcyjne nie pozwalają na głębsze analizowanie tu cech przypisywanych w Europie organom analogicznym do polskiego, konstytucyjnego modelu KRS, ale pośrednio wyrażona ocena TSUE nie jest zaskoczeniem. Mimo że wyrok dotyczył Izby Dyscyplinarnej SN, to rozstrzygnięcie TSUE niejako „rykoszetem” ugodziło w KRS i podniosło kwestię list poparcia jej obecnych członków do rangi papierka lakmusowego bezstronności sędziów przedstawionych do powołania z jej udziałem. Dzieje się tak, gdyż TSUE wprost nakazuje uwzględniać aktualny ustrój KRS i okoliczności jego wejścia w życie (przerwanie kadencji poprzedniej KRS), podporządkowując te czynności instrumentalnie budowaniu „zaufania” do sądu jako organu bezstronnego. Wynika to dosłownie z pkt 127-128 uzasadnienia wyroku (,stawką jest samo zaufanie, jakie każdy sąd powinien budzić w jednostkach w społeczeństwie demokratycznym"), pkt 143 (wymóg weryfikacji nieprawidłowości, jakimi mógł zostać dotknięty proces powoływania niektórych członków KRS, skrócenie kadencji KRS w 2017 roku oraz „wzrost liczby członków KRS z nadania sił politycznych lub przez nie wybranych do 23 z 25 członków”). Wyrok TSUE z 19 listopada 2019 roku nawiązuje również do dotychczasowego postrzegania interakcji między władzą wykonawczą i sądowniczą w ramach porządku konwencyjnego Rady Europy i rozstrzygania wątpliwości dotyczących bezstronności sędziego ${ }^{19}$.

Zagadnienie bezpośredniego lub pośredniego wpływu egzekutywy na procedurę powołania sędziów poruszono także we wciąż aktualnym zaleceniu nr R(94)12 Komitetu Ministrów dla państw członkowskich dotyczącym niezawisłości, sprawności i roli sędziów ${ }^{20}$. Zasada I.2.(c) — „Ogólne zasady dotyczące niezależności sędziów" - głosi:

Jednakże tam, gdzie postanowienia konstytucji lub prawo oraz tradycja pozwalają na wybór sędziów przez rząd, powinny istnieć gwarancje zapewniające, że procedura wyboru sędziów jest przejrzysta i w praktyce niezależna, tak aby na decyzję nie wpływały inne powody aniżeli te związane z wymienionymi uprzednio obiektywnymi kryteriami [chodzi o zalety sędziego wynikające z kwalifikacji, uczciwości, umiejętności i wydajności - M.B. ${ }^{21}$ ]. Takimi gwarancjami mogłoby być na przykład jedno lub więcej rozwiązań: 1) specjalny niezależny, kompetentny organ doradczy rządu, za którego radą rząd w praktyce podąża; lub 2) prawo odwołania od decyzji do niezależ-

19 Zob. pkt 128 uzasadnienia wyroku TSUE z powołaniem na orzeczenia ETPC: z dnia 6 maja 2003 roku w sprawie Kleyn i in. przeciwko Niderlandom, CE:ECHR:2003:0506JUD003934398, $\S 191$ i przytoczone tam orzecznictwo; a także z dnia 6 listopada 2018 roku w sprawie Ramos Nunes de Carvalho e Sá przeciwko Portugalii, CE:ECHR:2018:1106JUD005539113, §§ 145, 147, 149 i przytoczone tam orzecznictwo.

${ }^{20}$ Recommendation No. R(94)12 to Member States on the Independence, Efficiency and Role of Judges (1994), https://www.coe.int/en/web/portal/home (dostęp: 24.02.2020).

${ }^{21}$ Stanowisko dotyczące oparcia powołania i awansu zawodowego na kryteriach merytorycznych jest bardzo silnie akcentowane przez Radę Konsultacyjną Sędziów Europejskich oraz Komisję Wenecką, ilekroć idzie o charakteryzowanie roli instytucji zbliżonych funkcjonalnie do polskiej KRS; zob. Report on the Independence of the Judicial System Part I: The Independence of Judges adopted by the Venice Commission at its 82nd Plenary Session (Venice, 12-13 March 2010), https:// www.venice.coe.int/webforms/documents/?pdf=CDL-AD(2010)004-e (dostęp: 25.02.2020). 
nej władzy; lub 3) władza, która zabezpiecza przed podjęciem decyzji wskutek nadmiernych lub niewłaściwych wpływów.

Rekomendacja CM/Rec(2010) Komitetu Ministrów dla państw członkowskich dotycząca niezawisłości, sprawności i roli sędziów z dnia 17 listopada 2010 roku $^{22}$ jest $\mathrm{w}$ tym zakresie jeszcze bardziej szczegółowa (zob. rozdział IV — „Rady Sądownictwa”) i można stwierdzić, że aktualny model KRS jej nie spełnia. W szczególności kwestia list poparcia pozostawała w opozycji do zasady nr 28 („Rady Sądownictwa powinny odznaczać się najwyższym poziomem przejrzystości wobec sędziów i społeczeństwa poprzez ustanawianie z góry przyjętych procedur oraz uzasadnionych decyzji”), a zwłaszcza zasady nr 27 („Nie mniej niż połowa członków takich rad powinna składać się z sędziów wybieranych przez sędziów z różnych szczebli sądownictwa oraz z poszanowaniem pluralizmu w obrębie sądownictwa"). Na marginesie dodam, że w porównawczym prawie konstytucyjnym poprzeczkę dla instytucjonalnych gwarancji postawiono jeszcze wyżej:

(4) Władzy wykonawczej lub ustawodawczej nie powinno się przyznawać jakiegokolwiek wpływu w procedurze wyboru sędziów i oskarżycieli publicznych. (5) Powinno ustanowić się Wysoką Radę ds. Sądownictwa. Wysokiej Radzie należy powierzyć powoływanie, kierowanie lub przeniesienie [na stanowisko służbowe - M.B.], awansowanie i środki dyscyplinarne dot. sędziów i oskarżycieli publicznych. Takie ciało powinno składać się z sędziów bądź posiadać co najmniej większościową reprezentację sędziów i oskarżycieli publicznych ${ }^{23}$.

Standardy te dowodzą niezbicie, że kwestia prawa dostępu do informacji i tworzenia ograniczeń w dostępie do informacji o sposobie wyłonienia obsady KRS i jej procedowania mają zasadnicze znaczenie, zarówno dla oceny konstytucyjności porządku prawnego i prawidłowej obsady sądu w zawisłym postępowaniu, jak i dla rozwiania wątpliwości przez samych obywateli. Wydawać by się mogło, że kwestia dostępu do list poparcia do KRS nie powinna być problemem, a mimo to nie zostały one udostępnione w przepisanym prawem terminie w odpowiedzi na wnioski złożone w styczniu 2018 roku. Pojawiły się — po pierwszych przeciekach prasowych z 6 lutego 2020 roku $^{24}$ — w Systemie Informacyjnym Sejmu dopiero 13 lutego 2020 roku $^{25}$.

W dalszej części wyjaśnię, że problem został skomplikowany nad wyraz sztucznie przez organy o charakterze politycznym, na przekór bardzo czytelnym przepisom art. 61 Konstytucji RP ${ }^{26}$, działu IVa uchwały Sejmu Rzeczypospolitej

$22 \mathrm{https}: / / \mathrm{rm} . c 0 e . i n t / 16807096 \mathrm{c} 1$ (dostęp: 24.02.2020).

23 D. Smilov, The judiciary: The least dangerous branch?, [w:] The Oxford Handbook of Comparative Constitutional Law, red. M. Rosenfeld, A. Sajó, Oxford 2012, s. 860.

${ }^{24}$ W. Czuchnowski, E. Ivanova, Ł. Woźnicki, Krajowa Rada Swoich. „,Wyborcza” ujawnia liste poparcia do nowej KRS, „Gazeta Wyborcza” 6.02.2020, s. 1. W artykule ujawniono jedynie listę poparcia członkini KRS Teresy Kurcyusz-Furmanik.

${ }^{25} \mathrm{http}: / /$ www.sejm.gov.pl/Sejm9.nsf/page.xsp/krs (dostęp: 13.02.2020).

${ }^{26}$ Nie wspominając już o art. 9, art. 54 ust. 1, art. 91 ust. 1 i 2 oraz dorobku ETPCz dotyczących art. 10 konwencji i dostępu do informacji znajdujących się w wyłącznym posiadaniu państwa; 
Polskiej z dnia 30 lipca 1992 roku $^{27}$ („Dostęp do informacji publicznej oraz do informacji o środowisku i jego ochronie”), a także ustawy z dnia 6 września 2001 roku o dostępie do informacji publicznej ${ }^{28}$ (stosowanej wprost przez Szefa Kancelarii Sejmu nie tylko w zakresie o charakterze czysto proceduralnym ${ }^{29}$ ).

\section{NEUTRALIZACJA AKSJOLOGICZNA ART. 61 KONSTYTUCJI RP. ODWRÓCENIE HIERARCHII ŹRÓDEŁ PRAWA I UPOLITYCZNIENIE DYSFUNKCJI USTAWODAWSTWA}

Długotrwała ${ }^{30}$, „faktyczna” 31 odmowa udostępnienia list poparcia przez Szefa Kancelarii Sejmu, powołującego się na art. 11c u.KRS ${ }^{32}$, a także kontrowersyjne włączenie się w ten spór Prezesa Urzędu Ochrony Danych Osobowych (dalej: $\mathrm{UODO})^{33}$, aspirującego do przejęcia kompetencji Szefa Kancelarii Sejmu w zakresie oceny przesłanek ograniczających prawo do informacji ${ }^{34}$, powinny bulwerso-

szerzej na ten temat zob. M. Bernaczyk, Prawo do informacji publicznej w Polsce i na świecie, Warszawa 2014, s. 124-133.

27 Tekst jedn. M.P. z 2019 r. poz. 1028 ze zm., dalej: Reg.Sejm.

${ }^{28}$ Dz.U. z 2019 r. poz. 1429, dalej: u.d.i.p.

${ }^{29}$ Por. art. 61 ust. 4 Konstytucji RP, ograniczający zakres przedmiotowy ustawy wyłącznie do „trybu”, co uniemożliwia wprowadzanie do regulaminów izb autonomicznych przesłanek odmownych bądź powołanie się na normy proceduralne w celu ograniczenia dostępu do informacji (chociażby uzasadnionego w świetle art. 61 ust. 3 Konstytucji RP).

${ }^{30}$ Wnioski o udostępnienie informacji publicznej wpłynęły do Sejmu pod koniec stycznia 2018 roku. Udostępnienie list nastąpiło w Systemie Informacyjnym Sejmu (w tak zwanym trybie bezwnioskowym; zob. art. 202a ust. 1 Reg.Sejm) dopiero 13 lutego 2020 roku, mimo że regulamin izby nakazuje udostępnienie tej informacji w ciągu 14 dni (zob. art. 202b Reg.Sejm w zw. $\mathrm{z}$ art. 13 ust. 1 u.d.i.p.).

31 Odmowa dostępu do informacji publicznej ze względu na prawo do prywatności powinna nastąpić na drodze decyzji administracyjnej (zob. art. 61 ust. 3, art. 16 w zw. z art. 5 ust. 2 zdanie pierwsze u.d.i.p.).

32 „Zgłoszenia kandydatów dokonane zgodnie z art. 11a i art. 11b Marszałek Sejmu niezwłocznie przekazuje posłom i podaje do publicznej wiadomości, z wyłączeniem załączników".

33 Zob. postanowienie Prezesa UODO z dnia 29 lipca 2019 roku (znak UODO: ZSPU.440.707.2019.AZ.I), udostępnione na stronie Rzecznika Praw Obywatelskich, https://www. rpo.gov.pl/sites/default/files/Postanowienie\%20Prezesa\%20UODO\%202.pdf (dostęp: 24.01.2020). Zob. także postanowienia WSA w Warszawie z dnia 20 stycznia 2020 roku, sygn. II SA/Wa 1927/19, II SA/Wa 2148/19 i II SA/Wa 2153/19 ze skarg na postanowienie Prezesa Urzędu Ochrony Danych Osobowych w przedmiocie czasowego ograniczenia przetwarzania danych osobowych, dostępne w „Biuletynie Informacji Publicznej” WSA w Warszawie, http://bip.warszawa.wsa.gov.pl/997/ postanowienia-wsa-w-warszawie-w-sprawach-o-sygn-akt-ii-sawa-192719-ii-sawa-214819-i-iisawa-215319.html (dostęp: 24.01.2020); oraz wyrok WSA w Warszawie z dnia 24 stycznia 2020 roku, sygn. II SA/Wa 1927/19, opublikowany w Centralnej Bazie Orzeczeń Sądów Administracyjnych, http://orzeczenia.nsa.gov.pl/ (dalej: CBOSA).

${ }^{34}$ Zob. s. 3, akapit pierwszy in fine uzasadnienia postanowienia Prezesa UODO z dnia 29 lipca 2019 roku. 
wać z prostego powodu - w obowiązującym stanie prawnym jawność i dostępność tych informacji wynika wprost $\mathrm{z}$ art. 61 ust. 1 i 2 Konstytucji RP oraz art. 5 ust. 2 zdanie drugie u.d.i.p., bez potrzeby skomplikowanej egzegezy. Zastanawiające jest również ogromne ryzyko karnoprawne ${ }^{35}$ i zawodowe podjęte przez Szefa Kancelarii Sejmu (powoływanego i odwoływanego przez Marszałka Sejmu; zob. art. 200 ust. 2 Reg.Sejm), gdyż to piastun tego organu ponosi odpowiedzialność karną ${ }^{36}$ za nieudostępnienie informacji publicznej wbrew ciążącemu na nim obowiązkowi (zob. art. 23 u.d.i.p. w zw. z art. 200 ust. 1 i art. 202a ust. 3 Reg.Sejm).

Interwencja Prezesa UODO oparta na niezwykle płytkiej argumentacji prawnej nadwątliła wizerunek tego urzędu, gdyż może być rozpatrywana właśnie jako motywowana politycznie próba immunizowania Szefa Kancelarii przed konsekwencjami zaniechania niezwłocznego udostępnienia list poparcia. Dodatkowo nie należy zapominać, że dostęp do „informacji o działalności” organów i osób pełniących funkcje publiczne (art. 61 ust. 1 Konstytucji RP), ewentualnie „dostęp do informacji o sprawach publicznych" (art. 1 ust. 1 u.d.i.p. ${ }^{37}$ ), mieści się w pojęciu „wolności uzyskiwania informacji” (ang. freedom of information, niem. Informationsfreiheit), o której mowa w motywie 4 preambuły do rozporządzenia Parlamentu Europejskiego i Rady (UE) 2016/679 z dnia 27 kwietnia 2016 roku w sprawie ochrony osób fizycznych w związku z przetwarzaniem danych osobowych i w sprawie swobodnego przepływu takich danych oraz uchylenia dyrektywy 95/46/WE (ogólne rozporządzenie o ochronie danych) ${ }^{38}$ : „,niniejsze rozporządzenie nie narusza $[\ldots]$ wolności wypowiedzi i informacji”39. Konsekwentne uzasadnianie długotrwałego nieudostępnienia potrzebą przestrzegania

35 Oczywiście należy uwzględnić wpływ unii personalnej ministra sprawiedliwości i prokuratora generalnego na efektywność i motywację do ścigania funkcjonariuszy publicznych odmawiających udostępnienia informacji publicznej obciążających prawnie lub co najmniej politycznie ministra sprawiedliwości. Analiza list poparcia udostępnionych 13 lutego 2020 roku dowodzi silnych związków personalnych sędziów popierających z delegacją do ministerstwa sprawiedliwości lub ich późniejszym awansem za sprawą kompetencji kreacyjnych ministra. Szerzej i szczegółowo w ujęciu liczbowym zob. Komunikat Forum Obywatelskiego Rozwoju (4/2020) z dnia 18 lutego 2020 roku „Jawność wyborów do nowej KRS: publikacja list nie kończy sprawy”, s. 3-4.

36 Odpowiedzialność karna spoczywa również na osobach, którym zdekoncentrowano te obowiązki w strukturze organizacyjnej Kancelarii Sejmu (por. art. 201 ust. 1 Reg.Sejm).

${ }^{37}$ Nie podejmuję się rozszerzania tego wątku, ale proszę czytelnika o świadomość, że w ciągu ostatnich dziesięciu lat doszło do nadania pojęciu „informacja o sprawie publicznej” znaczenia węższego, niż wynika to z wykładni art. 61 ust. 1 ab initio Konstytucji RP. Praktykę sądowoadministracyjną, którą obarczam współodpowiedzialnością za ten stan rzeczy, omawiam bardzo szczegółowo, z uwzględnieniem metodyki wykładni zasad, reguł i wartości konstytucji, na łamach monografii M. Bernaczyk, „Dokument wewnętrzny” jako ograniczenie konstytucyjnego prawa do informacji. Rozstrzyganie kolizji w teorii i praktyce prawa, Warszawa 2017.

${ }^{38}$ Dz.Urz. UE z 4.05.2016, L 119/1, dalej: RODO.

${ }^{39} \mathrm{Na}$ temat sformułowań freedom of information, access to information, a także prawidłowego i błędnego pojmowania relacji pomiędzy wolnością uzyskiwania informacji (art. 54 Konstytucji RP) a prawem do informacji o działalności państwa (art. 61 Konstytucji RP) zob. odpowiednio M. Bernaczyk, Prawo do informacji..., s. 34-35; oraz idem, ,Dokument wewnętrzny”... 
europejskiego prawa o ochronie danych osobowych ${ }^{40}$ ociera się o cynizm i wybiórcze podejście do reżimu prawnego UE. Wszak listy poparcia mają znaczenie dla oceny niezależności sądów, które chronią prawa podmiotowe jednostki (w tym prawo do ochrony danych osobowych).

Kolizja między art. 8 a 47 Karty Praw Podstawowych nie zachodzi w wypadku list poparcia sygnowanych przez sędziów (art. 5 ust. 2 zdanie drugie u.d.i.p.), co wynika z rozstrzygnięcia tej kolizji na demokratycznie uzasadnioną niekorzyść sędziów konstytucyjnie przez zmniejszony zakres ochrony ich prywatności. Potwierdza to wyrok Trybunału Konstytucyjnego z dnia 20 marca 2006 roku (sygn. K 17/05) ${ }^{41}$, dotyczący bezpośrednio kwestii ograniczenia prawa do prywatności osób pełniących funkcje publiczne. $\mathrm{Z}$ tego powodu bardzo krytycznie oceniam zarzuty i uzasadnienie wniosku złożone do Trybunału Konstytucyjnego 6 sierpnia 2019 roku przez grupę posłów na Sejm VIII kadencji (i ponowiony w Sejmie IX kadencji pod sygnaturą K 21/19). Wniosek złożony w trybie art. 191 ust. 1 pkt 1 motywowany jest potrzebą ochrony prywatności sędziów udzielających poparcia do $\mathrm{KRS}^{42}$, lecz pozostaje w sprzeczności z wcześniejszym wyrokiem Trybunału Konstytucyjnego w sprawie K 17/05. Nie zaskakuje też błędnym pojmowaniem obecnej roli Trybunału Konstytucyjnego jako organu odpowiedzialnego za legitymizację programu politycznego większości parlamentarnej.

W całej tej sprawie bulwersuje również niski poziom dyskursu prawnego dotyczącego prawnych podstaw udostępnienia wykazów (list) poparcia, zarówno ze strony dziennikarzy, polityków, jak i ekspertów. Dyskusja toczyła się bowiem w przestrzeni ustawowej, pozbawionej refleksji konstytucyjnoprawnej. Większości sejmowej odpowiedzialnej za kształt u.KRS udało się skutecznie przenieść spór prawny o dostęp do tych wykazów na poziom ustawy (u.d.i.p.), która stwarza zainteresowanym bardzo wątte gwarancje dostępu do dokumentów, ich posiadaczom zaś daje bardzo duże możliwości skutecznego zablokowania dostępu z powołaniem na utrwalone (nie mylić z „konstytucyjne”) rozumienie centralnego pojęcia u.d.i.p., to jest ,informacji o sprawie publicznej”. Paradoksalnie, tak często przywoływany w przestrzeni publicznej wyrok NSA z dnia 28 czerwca 2019 roku (sygn. I OSK 4282/18) ${ }^{43}$ nie przesądza wcale o obowiązku udostępnienia list, lecz zaledwie o obowiązku rozpatrzenia wniosku o ich udostępnienie. Wynika to zresztą z modelu kontroli sądowoadministracyjnej. Wbrew entuzjazmowi płynącemu ze strony komentatorów i opozycji parlamentarnej i związaniu

${ }^{40}$ Zob. „Komunikat [Centrum Informacyjnego Sejmu — M.B.] ws. udostępnienia informacji publicznej dot. wykazów sędziów, którzy udzielili poparcia kandydatom do KRS” z dnia 13 lutego $2020 \mathrm{roku}(11: 20)$ z powołaniem na art. 14 RODO, http://www.sejm.gov.pl/Sejm9.nsf/komunikat. xsp?documentId=D47DFCABF91EE0C8C125850D00394E8D (dostęp: 24.01.2020).

${ }^{41}$ Opublikowany w IPOTK.

${ }^{42}$ Tej troski próżno jednak szukać w wypadku art. 88a § 4 ustawy z dnia 27 lipca 2001 roku Prawo o ustroju sądów powszechnych.

43 Opublikowany w CBOSA. 
oceną prawną NSA w rozpatrywanej sprawie bardzo dwuznacznie odczytuję stanowisko NSA sprowadzające się do tezy, że posiadanie dokumentu nie rozstrzyga jeszcze o objęciu go zakresem przedmiotowym u.d.i.p., skoro musi zawierać „informację o sprawach publicznych” (którą w sprawie I OSK 4282/18 NSA rozumie równie ogólnie jako ,sprawy związane z istnieniem i funkcjonowaniem określonej wspólnoty publicznoprawnej"). Jest to jednak ukryte ograniczenie wyprowadzane przez sądy z otwarcia makrokompozycji ustawy (z art. 1 ust. 1, lecz nie art. 5 u.d.i.p.), nieznane art. 61 Konstytucji RP i niezgodne z nakazem możliwie precyzyjnego konstruowania ograniczeń praw podmiotowych w ustawie, aczkolwiek aprobowane bez głębszych wywodów w piśmiennictwie prawniczym ${ }^{44}$. W efekcie organy publiczne bardzo chętnie kwestionują ,publiczny” charakter informacji, posiłkując się orzecznictwem sądowoadministracyjnym, gdyż nawet ewentualna przegrana w pierwszym etapie sporu (to znaczy — zaliczenie przez sąd spornej informacji do ustawowej kategorii informacji o sprawie publicznej) odsuwa perspektywę udostępnienia na długie lata.

Objęcie dokumentu zakresem przedmiotowym u.d.i.p. (przybierające zwykle stylizację „,dokument XYZ stanowi informację publiczną”) oznacza tylko tyle, że wnioskowany dokument podlega normowaniu ustawy (w tym przepisów ograniczających z art. 5 u.d.i.p.), co wcale nie przesądza, że zostanie on udostępniony. Informacja publiczna to nie synonim informacji jawnej (a co za tym idzie - dostępnej). W przedkładanych analizach naukowych dotyczących struktury i charakteru norm art. 61 Konstytucji RP wskazywałem wielokrotnie, że taka konstrukcja u.d.i.p. jest niezgodna z językowymi dyrektywami wykładni tekstu konstytucyjnego. Nośnik (cyfrowy lub analogowy) kontrolowany (wytworzony lub zgromadzony) przez podmioty określone w art. 61 ust. 1 Konstytucji RP, zawierający jakąkolwiek treść zrozumiałą przez człowieka lub zaprogramowaną przezeń maszynę (dokument) wchodzi w zakres treściowy prawa do informacji o działalności organów władzy publicznej i osób pełniących funkcje publiczne. Państwo, chcąc ograniczyć dostęp do informacji, nie może zasłaniać się lingwistyczną ekwilibrystyką sądownictwa administracyjnego, lecz powinno wskazać ustawową podstawę ograniczenia uchwaloną w celu ochrony przed zagrożeniami

${ }^{44} \mathrm{O}$ tym, jak bardzo arbitralnym kwalifikatorem informacji staje się ów przepis, świadczy odmowa dziennikarzom i Sieci Obywatelskiej Watchdog Polska dostępu do orzeczeń dotyczących nabycia słynnej już krakowskiej kamienicy przez obecnego Prezesa Najwyższej Izby Kontroli. Przepisy u.d.i.p. wprost zaliczają treść orzeczeń sądów powszechnych, Sądu Najwyższego, sądów administracyjnych, sądów wojskowych, Trybunału Konstytucyjnego i Trybunału Stanu do kategorii informacji publicznych (art. 6 ust. 1 pkt 4 lit. a) tiret trzeci u.d.i.p.). Nie przeszkodziło to jednak stwierdzić Prezesowi Sądu Okręgowego w Krakowie, że wnioskowane informacje nie są informacjami o sprawach publicznych (zob. pismo Prezesa Sądu Okręgowego w Krakowie z dnia 22 listopada 2019 roku, Adm.SO.-01444-1-331/19, z powołaniem na identyczne piśmiennictwo co NSA w sprawie I OSK 4282/18 - I. Kamińska, M. Rozbicka-Ostrowska, Ustawa o dostępie do informacji publicznej. Komentarz, Warszawa 2016; M. Jabłoński, Udostępnianie informacji publicznej w trybie wnioskowym, Wrocław 2009, s. 151). 
wymienionymi w art. 61 ust. $3 \mathrm{w}$ zw. z art. 31 ust. 3 Konstytucji RP. Zamiast tego obywatelom oferuje się blisko dwuletnie postępowanie, które odsuwa weryfikację stanu zagrożenia wywołanego udostępnieniem dokumentu dla chronionych interesów prawnych na dalszy plan. Zamiast tego roztrząsa się oczywistą (z perspektywy konstytucyjnej) kwestię, czy wykaz (lista) poparcia sporządzona pismem maszynowym lub ręcznym na kartce jest dokumentem o działalności podmiotów wymienionych w art. 61 ust. 1 Konstytucji RP.

Problem z (nie)przejrzystością państwa polskiego tkwi jednak w tym, że ustawodawca - mimo tak częstego odmawiania mu racjonalności — bardzo szybko dostosował się do metodyki sądowoadministracyjnej i rozpoczął jej swoiste „przepisywanie" na język ustawodawstwa. W efekcie w prawie polskim można spotkać wiele przepisów, które nie posługują się jakąkolwiek procedurą proporcjonalnego ograniczania dostępu (na przykład na drodze decyzji administracyjnej poprzedzonej wyważaniem prawa do informacji względem kolidujących wolności i praw innych osób lub innych interesów publicznych), lecz apriorycznie stwierdzają, iż „informacja XYZ nie stanowi informacji publicznej i nie podlega udostępnieniu na zasadach i w trybie ustawy z dnia 6 września 2001 r. o dostępie do informacji publicznej”. Polski reżim dostępu do informacji publicznej utknął w pułapce hipokryzji, skoro — zaniechawszy eliminacji dysfunkcyjnej normy art. 1 ust. 1 u.d.i.p. i tolerując przez dekadę jej pseudolimitacyjną funkcję nadaną przez orzecznictwo sądowoadministracyjne - negujemy ten sam mechanizm, lecz w wydaniu ustawodawcy „nie stanowi informacji publicznej dokument o sprawach XYZ” (co jest równoznaczne $\mathrm{z}$ twierdzeniem o nieobowiązywaniu normy ustawowej, która z mocy normy wyższego rzędu powinna przecież istnieć).

Nie możemy zapominać, że spór w sprawie I OSK 4282/18 został wszczęty ze skargi na decyzję administracyjną wydaną z powołaniem na art. 11c u.KRS ${ }^{45}$. Przepis ten został wyraźnie wskazany przez Szefa Kancelarii Sejmu jako podstawa odmowy dostępu do załączników (vel list, wykazów) obok niezależnej podstawy w postaci prawa do prywatności (zob. art. 5 ust. 2 zdanie pierwsze oraz art. 5 ust. 2 zdanie drugie a contrario u.d.i.p.). Struktura językowa art. 11c u.KRS — co trafnie zauważył NSA — sugeruje raczej modyfikację trybu udostępnienia, zakazując bezwnioskowego udostępnienia załączników w SIS (dostępnym 24 godziny na dobę nieograniczonej liczbie użytkowników z całego świata; trudno więc o bardziej „publiczne” podanie do wiadomości). Tym samym sąd wpadł jednak w pułapkę wynikającą z art. 61 ust. 4 Konstytucji RP. Jeśli art. 11c u.KRS modyfikuje tryb, to tym samym rażąco narusza dopuszczalny zakres normowania ustawą, zawężony (unikalnym na tle norm rozdziału II Konstytucji RP) art. 61 ust. 4 Konstytucji RP. Uważam, że ustawodawca upatrywał w art. 11c u.KRS zupełnie innej funkcji,

${ }^{45}$ Co i tak przewrotnie można uznać za działanie chwalebne, gdyż silące się na uzasadnienie stanowiska. W wypadku norm ustawowych wyłączających zastosowanie u.d.i.p. stanowisko sądów administracyjnych sprowadza się do nakazu skierowania pisma informującego (czynność materialno-techniczna) o niepodleganiu wnioskowanej informacji reżimowi dostępowemu. 
aczkolwiek tę intencję wyprowadzam spoza dokumentów związanych z przebiegiem procesu ustawodawczego, a mianowicie z wymienionego wcześniej wniosku grupy posłów do TK z dnia 6 sierpnia 2019 roku, a zwłaszcza ponownego wniosku z dnia 2 grudnia 2019 roku (sygn. K 21/19) ${ }^{46}$. Zapoznawszy się z tym ostatnim wnioskiem, gołym okiem widać, że wnioskodawcy chcą ulokować art. 11c u.KRS w granicach materialnych ograniczeń prawa do informacji (art. 61 ust. 3), a nie — jak ocenił to NSA - w zbiorze regulaminowych norm o charakterze proceduralnym. Gdyby art. 11c u.KRS przybrał nieco inne brzmienie, wprost wyłączające załączniki z zakresu normowania u.d.i.p., to całkiem możliwe, że w chwili sporządzania niniejszego tekstu nadal trwałyby starania o dostęp do tych informacji, być może w większym stopniu posadowione na płaszczyźnie konwencyjnej.

Kazus udostępniania list poparcia należy traktować jako ostrzeżenie przed tolerowaniem niespójności ustawowych form konkretyzacji praw jednostki z ich konstytucyjnym wzorcem. Okazują się one tykającą bombą wchodzącą w bardzo destrukcyjną synergię z innymi zaburzeniami ustroju władz publicznych. W praktyce nie widać woli politycznej do kompleksowego uregulowania tej sytuacji przez uchwalenie na przykład nowego prawa prasowego i zasad dostępu do informacji publicznej. Opinia publiczna musi odpowiedzieć sobie na pytanie, czy spektakularne spory o dostęp do informacji są w istocie toczone w celu jej uzyskania, czy zmierzają głównie do ukształtowania wizerunku organów obsadzonych przez przeciwników politycznych jako podmioty zwalczające jawność. W logice walki politycznej może mieścić się jedno i drugie, ale konstytucjonalizm i praworządność wzięta na poważnie zobowiązuje do konstruktywnej reformy prawa do informacji. Tej jednak wciąż brakuje, a ewentualne konstruktywne rozwiązania ograniczają się jedynie do derogacji na przykład obecnego art. 11c u.KRS ${ }^{47}$. Nie zmieni to jednak nominalnych i arbitralnych „gwarancji” dostępu do informacji o działalności władz publicznych, tkwiących w u.d.i.p.

\section{ACCESS TO AN AFFIDAVIT OF SUPPORT FOR CANDIDATES TO THE NATIONAL COUNCIL OF THE JUDICIARY AS AN EXAMPLE OF THE NEUTRALISATION OF THE POLISH CONSTITUTION}

\section{Summary}

The article concerns the obstruction of access to public records (affidavits of support for candidates to the Polish National Council of The Judiciary) by the Chancellery of the Sejm, despite its fundamental importance for assessment of the Council's constitutionality. The concerns expressed

46 Opublikowany w IPOTK.

47 Por. senacki projekt ustawy o zmianie ustawy o Krajowej Radzie Sądownictwa oraz niektórych innych ustaw z dnia 17 stycznia 2020 roku (druk senacki nr 50), opublikowany w „Biuletynie Informacji Publicznej”'Senatu RP, https:/www.senat.gov.pl/prace/senat/druki/ (dostęp: 24.02.2020). 
by the European Court of Justice on November 19th, 2019 in joint cases A.K. \& Others (C-585/18, C-624/18 and C-625/18) followed by Polish Supreme Court resolution BSA I-4110-1/20 of January 23rd, 2020 may boil down to the need of verifying the entire appointment process through the inspection of paper records held by the Sejm. The proactive disclosure of the crucial records by the Sejm in February 2020 took almost two years when the legal dispute regarding the Council's status had already been resolved by a Supreme Court resolution. Despite strong and clear constitutional provisions for access to such information (art. 54, 61 of the Constitution of Poland), the practical problem lies in the relatively inefficient freedom of information law weakened, ironically by the first victim of such a culture of secrecy, the judiciary itself, and the extreme reluctance of all political actors (including the opposition) in a parliamentary system of government to improve transparency. The article proves that there shall be no compromise over the scope and efficiency of the FOIA law if the records are of fundamental importance for the preservation of constitutional order.

Keywords: access to information, freedom of information, National Council of The Judiciary, The Constitution of Poland, separation of powers, judicial independence, Sejm, transparency

\section{BIBLIOGRAFIA}

Bałaban A., Krajowa Rada Sadownictwa - regulacja konstytucyjna i rola w systemie władzy sadowniczej, [w:] Sady i trybunały w Konstytucji i praktyce, red. W. Skrzydło, Warszawa 2005.

Bernaczyk M., ,Dokument wewnętrzny” jako ograniczenie konstytucyjnego prawa do informacji. Rozstrzyganie kolizji w teorii i praktyce prawa, Warszawa 2017.

Bernaczyk M., Prawo do informacji publicznej w Polsce i na świecie, Warszawa 2014.

Czuchnowski W., Ivanova E., Woźnicki Ł., Krajowa Rada Swoich. ,,Wyborcza” ujawnia listę poparcia do nowej KRS, „Gazeta Wyborcza” 6.02.2020.

Kamińska I., Rozbicka-Ostrowska M., Ustawa o dostępie do informacji publicznej. Komentarz, Warszawa 2016.

Jabłoński M., Udostępnianie informacji publicznej w trybie wnioskowym, Wrocław 2009.

Patyra S., Krajowa Rada Sadownictwa w Polsce, [w:] Rady sadownictwa w wybranych krajach europejskich, red. R. Balicki, S. Grabowska, M. Jabłoński, „Przegląd Prawa i Administracji” $119,2019$.

Piotrowski R., Demokracja nieliberalna, czyli oksymoron konstytucyjny, [w:] Potentia non est nisi ad bonum. Księa Jubileuszowa dedykowana Profesorowi Zbigniewowi Witkowskiemu, red. M. Serowaniec, A. Bień-Kacała, A. Kustra-Rogatka, Torun 2018.

Smilov D., The judiciary: The least dangerous branch?, [w:] The Oxford Handbook of Comparative Constitutional Law, red. M. Rosenfeld, A. Sajó, Oxford 2012.

Sokolewicz W., Funkcja kreacyjna Sejmu i Senatu, [w:] Parlament. Model konstytucyjny a praktyka ustrojowa, red. Z. Jarosz, Warszawa 2006.

Suchocka H., Zasada podziatu i zrównoważenia władz, [w:] Zasady podstawowe polskiej konstytucji, red. W. Sokolewicz, Warszawa 1998. 